\title{
Catalysts for Emerging Energy Applications
}

\author{
Bruce C. Gates (University of California-Davis, USA) \\ George W. Huber (University of Massachusetts-Amherst, USA) \\ Christopher L. Marshall (Argonne National Laboratory, USA) \\ Phillip N. Ross (Lawrence Berkeley National Laboratory, USA, retired) \\ Jeffrey Siirola (Eastman Chemical Company, USA) \\ Yong Wang (Pacific Northwest National Laboratory, USA)
}

\begin{abstract}
Catalysis is the essential technology for chemical transformation, including production of fuels from the fossil resources petroleum, natural gas, and coal. Typical catalysts for these conversions are robust porous solids incorporating metals, metal oxides, and/or metal sulfides. As efforts are stepping up to replace fossil fuels with biomass, new catalysts for the conversion of the components of biomass will be needed. Although the catalysts for biomass conversion might be substantially different from those used in the conversion of fossil feedstocks, the latter catalysts are a starting point in today's research. Major challenges lie ahead in the discovery of efficient biomass conversion catalysts, as well as in the discovery of catalysts for conversion of $\mathrm{CO}_{2}$ and possibly water into liquid fuels.
\end{abstract}

\section{What Is a Catalyst?}

Catalysts make chemical reactions go faster without being substantially consumed themselves. Although a catalyst changes the rate at which reactant molecules are converted into product molecules, it does not change the reaction equilibrium. If a reaction were to proceed all the way to equilibrium, the products and product distribution would be the same whether or not a catalyst were involved. However, many reactions do not proceed to equilibrium, and so a catalyst influences not just how fast the chemical change occurs, but also the distribution of products that are formed.

A catalyst works by opening a new reaction pathway that is impossible without it - that is, by combining chemically with reactant molecules and forming intermediates that are converted into products more rapidly than would be possible if the reactants were present alone. A catalyzed reaction is almost always characterized by a lower energy barrier than the same reaction when not catalyzed.

When a catalyst combines chemically with a reactant molecule, it forms an intermediate, which is usually converted in a sequence of steps into other intermediates and finally into products. Then the catalyst releases the product molecules and thereby becomes restored to its initial state, allowing it to combine with another reactant molecule and function again. Good catalysts undergo this process over and over again. Thus, catalytic reactions are cyclic, switching between the initial and final states with intermediate states along the way that involve partially or fully converted reactants. Ideally, a catalytic cycle continues without limit, but in reality, undesired changes render catalysts less active with continued use, and so the catalysts must be regenerated or replaced - to the benefit of the catalyst manufacturing industry.

Some catalysts increase rates of reaction by many orders of magnitude. A measure of how fast the reaction occurs is the catalytic activity. When reactants can be converted into various products, catalysts are chosen to favor the desired products; selectivity is a measure of how fast one reaction takes place relative to others and, thus, of how much the product(s) of that reaction dominate(s) in the overall product mixture. Stability accounts for the lifetime of a catalyst, and regenerability describes how well it responds to treatments to restore its activity and/or selectivity after operation.

\section{Importance of Catalysis in Biology and \\ Chemical Technology}

Catalysis is the key to almost all biological reactions - why they are fast and why they selectively produce the desired products. Most reactions in living organisms have their own catalysts, which have emerged through the process of evolution. Life as we know it is unimaginable without the deft control of chemical change provided by enzymes.

Catalysis is also the essential enabling technology of industrial chemical conversion. ${ }^{1}$ Most industrial reactions are catalyzed. Specifically, catalysis enables the cost-effective and environmentally sound production of fuels (e.g., transportation fuels), polymeric materials (polypropylene, polyester fibers), nanomaterials (carbon nanotubes), chemicals (ammonia, methanol, flavors, fragrances), foods (hydrogenated fats), and pharmaceuticals (pain relievers). The value of the goods manufactured annually in the United States in processes that involve catalysts is estimated to be several trillion dollars; the cost of the new and replacement catalysts is only about $1 \%$ of the value of these goods.

Catalysts are also crucial to the abatement of pollutants, including exhaust from motor vehicles (converting unburned fuel, $\mathrm{CO}$, and nitrogen oxides) and effluents from fossil fuel power plants. These technologies have markedly improved the quality of Earth's atmosphere. 


\section{The Nature of Catalytic Materials}

The simplest catalysts are molecules or ions in solution. ${ }^{2}$ Nature's catalysts (enzymes) are extremely large molecules (proteins) that are present in solutions or anchored to soft materials, such as membranes. The typical catalyst used in an industrial process is a robust inorganic solid, often capable of withstanding temperatures of hundreds of degrees Celsius. Most catalysts used for large-scale petroleum and natural gas processing are such materials, consisting of metal oxides, metal sulfides, and/or metals. Metal oxides are typically the major components.

Solid catalysts offer engineering advantages over liquids, being noncorrosive and inexpensively separated from fluidphase products. They can be used at high temperatures (favoring high rates of reaction) without high pressures (which incur high costs), because the reactants can be in the gas phase. In contrast, liquid catalysts used at high temperatures require high pressures to maintain the liquid state.

Reactions catalyzed by a solid take place on its surface. To maximize rates of catalytic reactions and minimize reactor volumes, catalysts have high surface areas per unit volume, sometimes hundreds of square meters per gram (a few grams held in the hand would have the internal area of several football fields). To present such large areas, solids must have small pores (e.g., Figure 1), typically tens of nanometers in diameter. The pores are usually void spaces between aggregates of small particles with dimensions similar to the pore diameter; the aggregates comprising a whole catalyst pellet or particle are sometimes held together by binders such as vitrified clays.
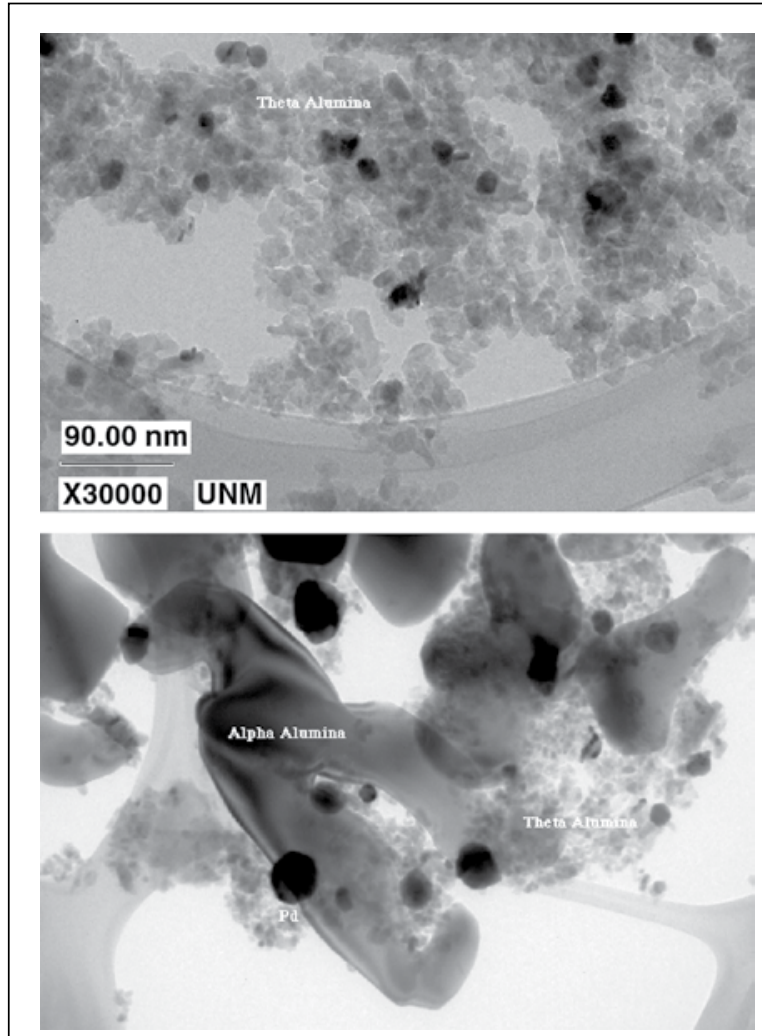

Figure 1. Transmission electron microscope (TEM) image of palladium particles on the porous catalyst support $\mathrm{Al}_{2} \mathrm{O}_{3} \cdot{ }^{3}$ Top: before treatment; bottom (at the same magnification): after treatment for $96 \mathrm{~h}$ at $900^{\circ} \mathrm{C}$ in steam resulting in phase changes in the support and sintering of the palladium.
Physical properties affecting catalyst performance include the surface area, pore volume, and pore size distribution. These regulate a tradeoff between the rate of the catalytic reaction on the internal surface of the catalyst and the rate of diffusion of reactant molecules into the pores and product molecules out of the pores. The higher the internal area, the higher the rate of the reaction per unit volume - up to a limit, beyond which an increase in area requires such narrow pores that they restrict the diffusion enough to lower the overall reaction rate. If internal area is gained at the expense of increased pore volume, a limit is reached at which the material is no longer strong enough to support the weight of particles above it.

Catalyst particles have various shapes, dictated by the cost of manufacturing and the requirements of the process. Irregular particles and even hollow particles are occasionally used, but more commonly, the particles are cylindrical or spherical. Spherical particles can be formed, for example, by spray drying, and they offer the advantage of being easily transferred in bulk into and out of reactors. Cylindrical particles are commonly used and are formed by extrusion; pellets are common and are formed by granulation and compaction.

The particle size and shape might be dictated by the need to minimize the resistance to transport of reactants and products in the pores; thus, a goal might be to have a high ratio of peripheral surface area to particle volume and to minimize the average distance from the peripheral surface to the particle center without having particles that are so small as to cause a large pressure drop in the flow of reactants through the reactor.

Many catalysts are composite materials, consisting of a carrier or support (often constituting as much as about $99 \%$ of the total mass and lacking catalytic activity itself), combined with components having catalytic activity and possibly promoters. Typical supports are aluminas (e.g., $\gamma-\mathrm{Al}_{2} \mathrm{O}_{3}$ or $\eta-\mathrm{Al}_{2} \mathrm{O}_{3}$ ), silica gel, zirconia, magnesia, zeolites, and carbon. Aluminas, for example, offer the advantages of being inexpensive, robust, and stable, and having the ability to be formed into particles with wide ranges of shapes, internal surface areas, and pore size distributions.

Metal oxides are sometimes catalysts themselves, but often, they are used as supports and are chemically inert. In such cases, the catalyst incorporates only a small amount of catalytically active components (e.g., metals, metal sulfides, or metal oxides other than the support) dispersed on the internal surface of the support (Figure 2). Because these components are often expensive, they are present as nanoparticles, exposing a large

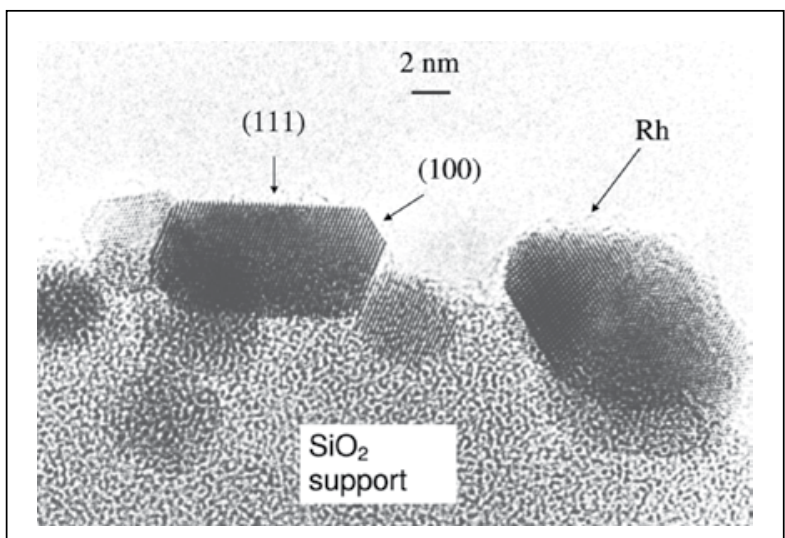

Figure 2. TEM image (profile view) of a supported metal catalyst: rhodium on silica gel. The metal nanoparticles are cubo-octahedral and exhibit (111) and (100) facets. ${ }^{4}$ 
fraction of their atoms at a surface where catalysis can occur. Components as expensive as precious metals such as platinum and palladium necessitate technology for their recovery and recycling after use.

The performance of a catalyst can be improved by an added promoter or killed by an adventitious poison entering with the reactant feed stream. Catalyst promoters lack significant activity themselves, but they make a catalyst more active, selective, or stable. A chemical promoter is used in minute amounts to affect the chemistry of catalysis by influencing or being part of the catalytically active surface sites. A textural (structural) promoter is used in large amounts and plays a role such as stabilization of the catalyst, for instance, by minimizing its tendency to sinter.

Because many catalysts incorporate potentially toxic components such as heavy metals, proper precautions must be taken for their disposal.

\section{Catalytic Reactors}

Catalysts in large-scale processes are used in flow reactors, including fixed-bed reactors, in which the catalyst particles remain fixed in place and fluid-phase reactants flow around the particles (through the interstitial bed volume). These reactors are typically cylindrical, some large and some small in diameter, such as pipes (which can be used singly or in banks; i.e., parallel reactors), sometimes surrounded by flowing fluids to remove or supply heat. When the reactor is a fixed bed, the catalyst particles in the vessel must be large enough to cause minimal pressure drop of the reactant/product mixture flowing through it; too high a pressure drop implies high energy losses associated with the flow through the tube. A typical dimension of a catalyst particle is in the range of $0.5-3 \mathrm{~cm}$.

Some reactors (e.g., those used for automobile exhaust conversion) are monoliths (honeycombs) with the catalytically active components present in thin porous coatings on the channel walls; these reactors allow high gas flow rates with low pressure drops, a requirement for optimal efficiency of the engine.

In moving-bed reactors, the catalyst particles are "fluidized" or levitated by the momentum of the flowing reactant mixture. When a fluidized-bed reactor contains a liquid phase, it is called a slurry reactor. Catalyst particles used in fluidized beds are usually spherical, having the size distribution needed to facilitate fluidization without carryover of the smallest particles. The particles are in constant motion and must have resistance to abrasion - their most important physical property. Abrasion inevitably turns the original particles into smaller particles (fines). Equipment such as cyclones is necessary to collect the fines and minimize damage to downstream equipment. When the fines are too small for recycling, they are removed and replaced with fresh catalyst particles.

Alternatively, the catalyst particles in a fluidized reactor might intentionally be small (e.g., spheres about $50 \mu \mathrm{m}$ in diameter) and light enough to be carried out with the products (entrained), to be separated downstream and recycled to the reactor. In the process for gasoline manufacturing by catalytic cracking of fractions of crude oil (separated by distillation), the catalyst particles are carried over into a separate reactor, where the carbonaceous deposits that form in only a few seconds in the cracking reactor are burned off during catalyst regeneration.

\section{Catalysis of Fossil Fuel Production}

The dominant catalytic processes for energy conversion have been developed for petroleum, natural gas, and coal (e.g., Table I). ${ }^{5}$ (See the article by Holditch et al. with the sidebar by Rath and the article by Powell and Morreale in this issue for further discussion of these industries.) Related processes include abatement of automobile and power-plant emissions and conversion of $\mathrm{H}_{2}$ in fuel cells (also see the article by
Crabtree et al. in this issue). A brief introduction to et al. processes for catalytic fossil fuel conversion provides a useful basis for addressing the prospects for catalysis of biomass conversion.

Refining of petroleum to yield liquid transportation fuels and petrochemicals involves fractionation (distillation) of crude oil into various boiling ranges. Catalytic conversions of the various fractions are then carried out to meet a number of processing goals: removal of sulfur, nitrogen, and metals from the oil molecules; cracking of large molecules into smaller ones; reactions of small molecules to give larger ones (e.g., alkylation); and restructuring (reforming) reactions of molecules that improve fuel quality without changing the molecular weight significantly. The processes almost all either involve $\mathrm{H}_{2}$ as a reactant (e.g., in hydrodesulfurization, HDS; hydrodenitrogenation, HDN; and hydrodemetallization, HDM; which respectively produce $\mathrm{H}_{2} \mathrm{~S}, \mathrm{NH}_{3}$, and solid metal sulfides) or result in the transfer of hydrogen atoms between molecules (e.g., in cracking and reforming). The catalysts are primarily solid acids (for cracking), some of which contain precious metals such as platinum (for reforming, hydrocracking) or metal sulfides (for HDS, HDN, and HDM).

Valuable light, sweet crude oils having low contents of highmolecular-weight molecules and contaminants such as sulfur and nitrogen are being depleted rapidly, because they incur the lowest processing costs. Meanwhile, ever-stricter environmental regulations are demanding greater removal of sulfur to minimize sulfur oxide air pollutants resulting from fuel combustion.

As a result, the petroleum industry is increasingly exploiting heavy petroleum and oil-sands-derived bitumen, and ample supplies of these feedstocks appear to be available to meet energy needs for decades to come. All of the heavy feedstocks can be processed with modifications of existing catalytic technology, but heavy oils, shale, and coal generally have higher contents of contaminants than light oils and require more $\mathrm{H}_{2}$ in the processing, specifically for HDS, HDN, and HDM. Moreover, they all incur much higher processing costs than light, sweet crude oils, which, unlike the heavy feedstocks, are net sources of $\mathrm{H}_{2}$ (produced in the reforming process).

Coal can be converted into liquid fuels by liquefaction, which is barely applied today and involves reaction of the coal with hydrogen or a hydrogen-donating solvent to make liquids suitable for refining. Coal can also be converted by gasification, which is widely applied and involves reaction with steam at high temperatures to form mostly $\mathrm{H}_{2}+\mathrm{CO}$, known as synthesis gas (syngas). Fischer-Tropsch catalysts convert syngas to hydrocarbons for diesel fuel, and other products of this process include compounds incorporating oxygen (alcohols, aldehydes, ketones). Catalysts different from those used in Fischer-Tropsch processes convert syngas selectively to methanol, which is used extensively as a chemical and has also been considered as a valuable transportation fuel itself, ${ }^{6}$ even potentially for fuel-cell vehicles, although it has not been adopted by the market.

The technology of coal gasification and the production of liquid fuels from syngas are important in the context of the prospects for catalytic biomass conversion, because biomass can be converted similarly.

Natural gas, like coal, is converted with steam to give syngas, and this is an important source of $\mathrm{H}_{2}$; the yields of $\mathrm{H}_{2}$ are increased by application of the water-gas shift reaction, whereby water reacts catalytically with the $\mathrm{CO}$ in syngas to form $\mathrm{H}_{2}$ and $\mathrm{CO}_{2}$. Fischer-Tropsch catalysts are used to convert the sulfur-free syngas formed from natural gas to produce mixtures of waxy straight-chain alkanes, which are catalytically hydrocracked to yield diesel fuels. In what is called gas-to-liquids technology, 


\begin{tabular}{|c|c|c|c|c|}
\hline Reaction & Reactants & Major Products & $\begin{array}{l}\text { Typical Industrial } \\
\text { Catalyst }\end{array}$ & $\begin{array}{l}\text { Reactor } \\
\text { Type }\end{array}$ \\
\hline Cracking & $\begin{array}{l}\text { Petroleum fractions } \\
\text { (e.g., straight- } \\
\text { chain alkanes, } \\
\text { cyclic alkanes) }\end{array}$ & $\begin{array}{l}\text { Lighter } \\
\text { hydrocarbons } \\
\text { (alkanes and } \\
\text { alkenes) }\end{array}$ & $\begin{array}{l}\text { Acidic zeolite in } \\
\text { matrix of silica- } \\
\text { alumina with } \\
\text { components to } \\
\text { oxidize } \mathrm{CO}(\mathrm{Pt}) \\
\text { and sequester } \\
\text { sulfur oxides }\end{array}$ & $\begin{array}{l}\text { Entrained } \\
\text { bed }\end{array}$ \\
\hline Naphtha reforming & $\begin{array}{l}\text { Petroleum-derived } \\
\text { naphtha (e.g., } \\
\text { straight-chain } \\
\text { alkanes, cyclic } \\
\text { alkanes) }\end{array}$ & $\begin{array}{l}\text { Aromatic } \\
\text { compounds, } \\
\text { isomerized } \\
\text { (branched) } \\
\text { alkanes }\end{array}$ & $\begin{array}{l}\text { Pt nanoclusters } \\
\text { with another } \\
\text { metal (Re, Sn, } \\
\text { or Ir) supported } \\
\text { on } \mathrm{Al}_{2} \mathrm{O}_{3}\end{array}$ & $\begin{array}{l}\text { Fixed bed or } \\
\text { moving } \\
\text { bed }\end{array}$ \\
\hline $\begin{array}{l}\text { Hydrodesulfurization } \\
\text { (HDS) }\end{array}$ & $\begin{array}{l}\text { Sulfur-containing } \\
\text { compounds in } \\
\text { fossil feedstocks } \\
\text { (e.g., thiophene, } \\
\text { dibenzothiophene) }\end{array}$ & $\begin{array}{l}\mathrm{H}_{2} \mathrm{~S} \text { and } \\
\text { hydrocarbons } \\
\text { (e.g., butenes, } \\
\text { biphenyl) }\end{array}$ & $\begin{array}{l}\mathrm{MoS}_{2} \\
\text { nanoclusters } \\
\text { promoted } \\
\text { with } \mathrm{Co} \text { and } \\
\text { supported on } \\
\mathrm{Al}_{2} \mathrm{O}_{3}\end{array}$ & $\begin{array}{l}\text { Fixed bed } \\
\text { (typically } \\
\text { trickle } \\
\text { bed) or } \\
\text { slurry }\end{array}$ \\
\hline $\begin{array}{l}\text { Hydrodenitrogenation } \\
\text { (HDN) }\end{array}$ & $\begin{array}{l}\text { Nitrogen-containing } \\
\text { compounds in } \\
\text { fossil feedstocks } \\
\text { (e.g., quinoline, } \\
\text { triglycerides) }\end{array}$ & $\begin{array}{l}\mathrm{NH}_{3} \text { and } \\
\text { hydrocarbons }\end{array}$ & $\begin{array}{l}\mathrm{MoS}_{2} \\
\text { nanoclusters } \\
\text { promoted } \\
\text { with Ni and } \\
\text { supported on } \\
\mathrm{Al}_{2} \mathrm{O}_{3}\end{array}$ & $\begin{array}{l}\text { Fixed bed } \\
\text { (typically } \\
\text { trickle } \\
\text { bed) or } \\
\text { slurry }\end{array}$ \\
\hline $\begin{array}{l}\text { Hydrodeoxygenation } \\
\text { (HDO) }\end{array}$ & $\begin{array}{l}\text { Oxygen-containing } \\
\text { compounds coal } \\
\text { or biomass- } \\
\text { derived feedstocks } \\
\text { (e.g., phenol, } \\
\text { sugars) }\end{array}$ & $\begin{array}{l}\mathrm{H}_{2} \mathrm{O} \text { and } \\
\text { hydrocarbons } \\
\text { (e.g., benzene) }\end{array}$ & $\begin{array}{l}\mathrm{MoS}_{2} \\
\text { nanoclusters } \\
\text { promoted with } \\
\mathrm{Co} \text { or Ni and } \\
\text { supported on } \\
\mathrm{Al}_{2} \mathrm{O}_{3}\end{array}$ & $\begin{array}{l}\text { Fixed bed or } \\
\text { slurry }\end{array}$ \\
\hline Water-gas shift & $\mathrm{CO}+\mathrm{H}_{2} \mathrm{O}$ & $\mathrm{CO}_{2}+\mathrm{H}_{2}$ & $\begin{array}{l}\text { Iron oxide/chrom- } \\
\text { ium oxide or } \mathrm{Cu} \\
\text { supported on } \\
\mathrm{Al}_{2} \mathrm{O}_{3} \text { with } \mathrm{ZnO}\end{array}$ & Fixed bed \\
\hline $\begin{array}{l}\text { Fischer-Tropsch } \\
\text { synthesis }\end{array}$ & $\mathrm{CO}+\mathrm{H}_{2}$ & $\begin{array}{l}\text { Straight-chain } \\
\text { alkanes, } \\
\text { alkenes, } \\
\text { oxygen- } \\
\text { containing } \\
\text { compounds } \\
\text { such as } \\
\text { alcohols, } \\
\text { aldehydes, and } \\
\text { ketones }\end{array}$ & $\begin{array}{l}\text { Bulk iron } \\
\text { promoted with } \\
\text { alkali metal or } \\
\text { Co particles on } \\
\text { a support }\end{array}$ & $\begin{array}{l}\text { Fixed bed or } \\
\text { slurry }\end{array}$ \\
\hline Methanol synthesis & $\mathrm{CO}+\mathrm{H}_{2}$ & $\begin{array}{l}\text { Methanol (with } \\
\left.\qquad \mathrm{CO}_{2} \text { and } \mathrm{H}_{2} \mathrm{O}\right)\end{array}$ & $\begin{array}{l}\text { Cu supported on } \\
\qquad \mathrm{Al}_{2} \mathrm{O}_{3} \text { with } \mathrm{ZnO}\end{array}$ & $\begin{array}{l}\text { Fixed bed or } \\
\text { possibly } \\
\text { slurry }\end{array}$ \\
\hline
\end{tabular}

could sustainably produce 1.3 billion tons of low-cost lignocellulosic biomass annually without detrimental effects on its food, feed, or export demands. ${ }^{7}$ This amount of biomass has the energy content of 3.8 billion barrels of oil; and the U.S. consumption of oil is about 7 billion barrels/year.

Fuels from biomass are already available on a large scale. Fermentation processes in Brazil today produce ethanol for fuel from sugar cane, and the United States, with subsidies of $\$ 0.5 /$ gallon, similarly produces ethanol for gasoline from corn starch (the cost of the ethanol is an important issue). The United States, Europe, and Asia also produce diesel fuel from vegetable oils, primarily by transesterification, and new processes are currently being developed.

A grand challenge facing the world is the creation of technology for economical conversion of the major components of lignocellulosic or woody plants (cellulose, hemicellulose, and lignin) into liquid fuels; there is also interest in conversion of vegetable oils, algae, and other sources that could be available in large quantities. These plant materials are described briefly here in the context of the prospects for their catalytic conversion to liquid fuels (also, for more on biofuels and catalysts, see the article by Farrell et al. and the accompanying sidebars by Wyman and Gust et al. in this issue).

Cellulose is a linear crystalline polymer consisting of $\beta-1,4$ linkages of the six-carbon sugar, D-glucose (Figure 3a), typically containing 200-10,000 glucose units per chain. Hemicellulose is a branched amorphous polymer comprising mixtures of the

such processes have been implemented recently in locations with significant natural gas resources but insufficient infrastructure to move it efficiently to distant markets.

\section{Prospects for Catalytic Conversion of Biomass Biomass as a Feedstock for a Sustainable Energy Supply}

Burning carbon-containing fuels emits $\mathrm{CO}_{2}$ into the atmosphere, but growing biomass consumes $\mathrm{CO}_{2}$ by photosynthesis - so the growth of biomass can offset the $\mathrm{CO}_{2}$ generation. This opportunity for $\mathrm{CO}_{2}$ recycling provides a strong motivation for the development of economical routes to convert biomass into liquid fuels. It is estimated that the United States five-carbon sugars xylose and arabinose (in hardwoods) and six-carbon sugars including glucose, mannose, and rhamnose (in softwoods). Figure 3b shows some of these building blocks. Sugar acids such as mannuronic and glacturonic acids are also found in hemicellulose. Hemicellulose molecules typically contain 50-200 sugar units.

Wood and herbaceous crops contain 60-68\% (dry basis) cellulose plus hemicellulose, which can be hydrolyzed into their constituent sugar monomers, such as glucose, xylose, and arabinose, and other five- and six-carbon sugars. Lignin, a large, randomly constructed and highly aromatic cross-linked macromolecule with molecular weights of $>10,000$ (Figure 4), makes up $10-25 \%$ of such plants. 

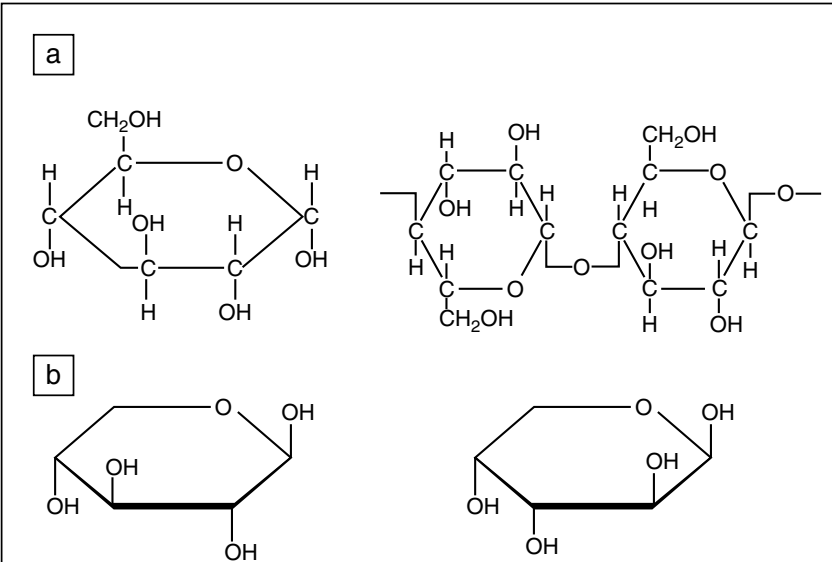

$\beta$-D-Arabinopyranose

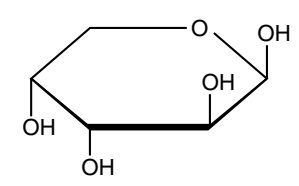

$\beta$-D-Xylopyranose

Figure 3. (a) $\beta$-D-glucose unit (left) and two $D$-glucose units in a $\beta$-linkage (right). (b) Comparison of the $\beta$-pyranose forms of $\mathrm{D}$-arabinose and $\mathrm{D}$-xylose.

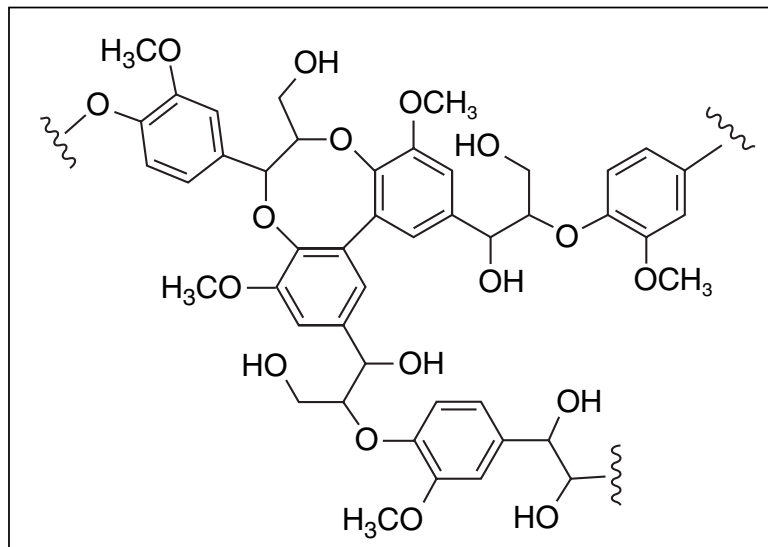

Figure 4. Representative portion of a lignin macromolecule.

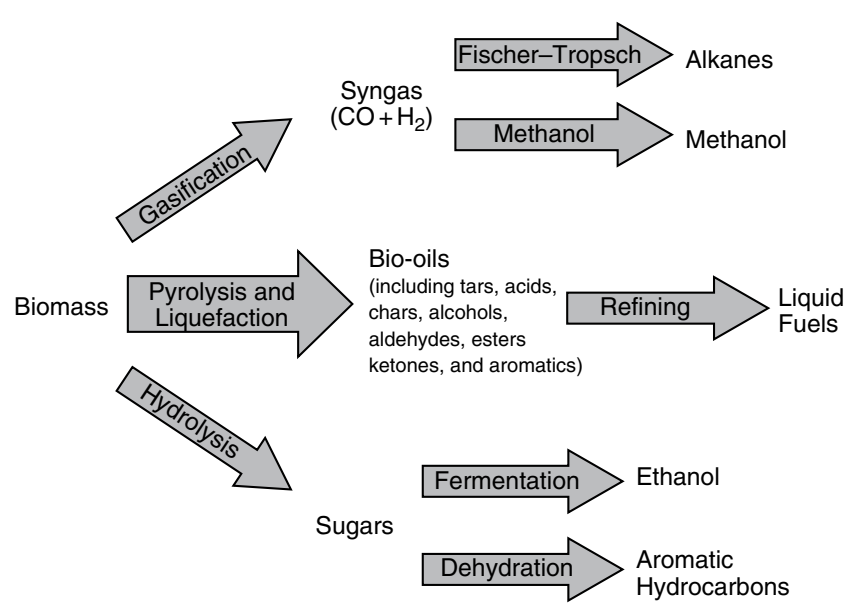

Figure 5. Routes to the production of fuel components from biomass. ${ }^{8}$

Some routes for the production of fuel components from biomass that have been demonstrated in at least a preliminary way are shown in Figure 5 and described in the following sections.

\section{Comparison of Biomass and Fossil Fuel Feedstocks}

In contrast to petroleum and natural gas, which are mostly hydrocarbons, biomass contains a high percentage of oxygen and components with low hydrogen/carbon ratios. The oxygencontaining molecules from biomass have lower energy densities than the hydrocarbons in gasoline with comparable molecular weights. Thus, a major challenge in biomass processing to liquid fuels is the removal of oxygen. However, the removal of oxygen from biomass might not need to be complete; good candidate fuel components with low oxygen contents include ethanol, butanols, furans, and esters, including biodiesel.

Hydrogen is needed for the production of biofuels from biomass feedstocks. The hydrogen can be produced from the biomass itself or from other sources. If it is not economical to produce hydrogen from biomass, then the overall conversion will involve oxygen removal as $\mathrm{CO}_{2}$ and $\mathrm{H}_{2} \mathrm{O}$ (and possibly $\mathrm{CO}$ ). If hydrogen from non-biomass sources is more economical, then oxygen will be removed from biomass as water formed by reaction with hydrogen.

Because cellulosic biomass is a solid, it will require processing that is substantially different from that applied in natural gas or petroleum conversion. For catalytic processing by non-biological routes, biomass will first have to be deconstructed into molecules small enough to be brought into effective contact with catalysts. One might therefore anticipate some similarities between the technology for coal conversion and future technologies for biomass conversion-because both coal and biomass are solids that contain carbon, hydrogen, and oxygen. However, many coals contain a great deal of bulk mineral matter mixed with the organic matter, whereas biomass does not, and biomass, like petroleum, contains organically bound metals that affect catalysts used in its conversion and downstream processing. Cellulosic biomass can also be deconstructed at significantly lower temperatures than coal because of its high oxygen content; thus, the door is open to low-temperature deconstruction methods such as acid-catalyzed hydrolysis and fast pyrolysis.

\section{Conversion of Biomass through Syngas}

An obvious option that is already practiced industrially is to convert biomass directly into syngas by gasification. ${ }^{9}$ The technology differs from that applied to coal, because biomass is much less stable and contains significant amounts of sodium, potassium, and other alkali metals that can cause slagging and fouling problems in conventional gasification equipment used at the low temperatures appropriate for biomass. Gasification of biomass gives higher yields of tars than gasification of coal. The conversion and cleanup of these tars is a significant technological challenge.

Recent research by the group of Schmidt ${ }^{9,10}$ introduced novel routes for the conversion of biomass-derived liquids and even wood itself directly into syngas with low yields of tars in high-temperature low-contact-time catalytic flow reactors. Wood particles are almost instantaneously vaporized at the upstream end of a small, hot flow reactor employing a rhodium catalyst containing cerium oxide supported on an $\alpha-\mathrm{Al}_{2} \mathrm{O}_{3}$ foam, and the conversion takes place with a contact time of $<70 \mathrm{~ms}$ (Figure 6). The process is conceptually simple, and the reactor is small for a given throughput, offering promise for future applications. This example illustrates how innovations in catalysis can improve yields of desired reaction products, but 


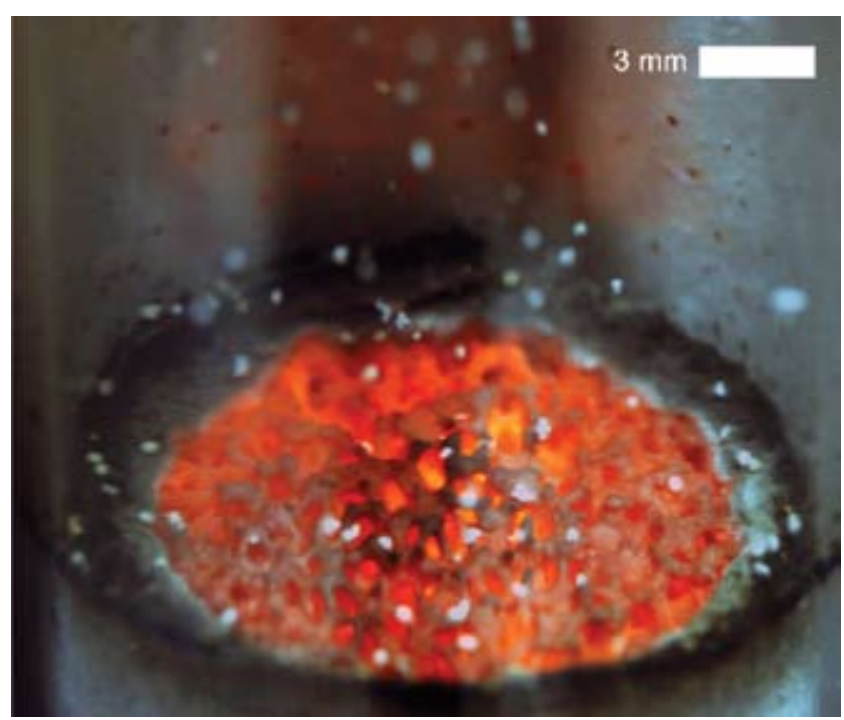

Figure 6. Front face of a catalyst during reforming of approximately $230-\mu \mathrm{m}$ particles of cellulose in air. ${ }^{11}$

before a process of this type can be employed commercially, the lifetimes of the catalyst will have to be shown to be sufficient to justify the use of the expensive metal rhodium.

\section{Conversion of Biomass through Sugars and Other Small Organic Compounds}

In nature, cellulose is broken up into sugars by the action of enzymes (cellulases); these biological catalysts work from the ends of the macromolecule and also at the linkages of the sugar units. Cellulases can give nearly $100 \%$ yields of glucose. Liquid acids can be used instead of enzymes to catalyze cellulose deconstruction by hydrolysis, giving much higher rates of reaction than can be obtained with enzymes (the reactions take hours rather than days). However, acid-catalyzed hydrolysis gives products such as levulinic acid that, in contrast to glucose, cannot be converted by fermentation.

The near-term opportunities for catalysis by solids would seem to lie less in the conversion of solid biomass itself (innovations would be needed to make this feasible) and more in the conversion of the small organic molecules formed from cellulose, hemicellulose, and/or lignin by enzymatic reactions or acid hydrolysis.

The conversions of these small organic compounds bear some relationship to the conversions of the oxygen-containing organic compounds formed in Fischer-Tropsch synthesis that have been summarized in the processing literature. ${ }^{12,13}$ The catalysts that have been investigated so far are essentially the same as those investigated previously for the conversion of petroleum and petrochemicals. Much research is needed to find optimum catalysts for these conversions; they might require supports as well as catalytic components different from those used in fossil fuel conversion.

For example, because some of the reactions (e.g., alcohol dehydration) produce high yields of water, it will be essential to find catalysts that are stable in water. The catalysts used in petroleum refining do not encounter much water, but when they do, they undergo degradation (e.g., the zeolites used in cracking to make gasoline, which are regenerated by the burning of the carbonaceous deposits formed during catalysis, coming in contact with high-temperature steam).
The biomass-derived oxygenated compounds typically have low thermal stabilities, associated with their high oxygen contents, making it difficult to process them as gas-phase reactants under conditions used for most petroleum refining reactions. This limitation motivates catalysis with reactants in the liquid phase, as illustrated in pioneering research by the group of Dumesic. ${ }^{14-16}$ They recently reported catalyst performance data illustrating potential processes for the conversion of sugars, sugar alcohols, and polyols into $\mathrm{H}_{2}$ and $\mathrm{C}_{1}-\mathrm{C}_{15}$ alkanes. $\mathrm{H}_{2}$, $\mathrm{CO}_{2}, \mathrm{CO}$, and light alkanes were produced from sugar or sugarderived feeds in the presence of liquid water and a solid catalyst at $200-260^{\circ} \mathrm{C}$ and $10-50$ bar.

The catalytic pathway that produces maximum yields of $\mathrm{H}_{2}$ and $\mathrm{CO}_{2}$ involves cleavage of $\mathrm{C}-\mathrm{C}, \mathrm{C}-\mathrm{H}$, and $\mathrm{O}-\mathrm{H}$ bonds to form intermediate $\mathrm{C}-\mathrm{OH}_{x}$ species ( $x$ is not well known) on the catalyst surface, followed by removal of these species by the water-gas shift reaction. A good catalyst for production of $\mathrm{H}_{2}$ must facilitate $\mathrm{C}-\mathrm{C}$ bond cleavage and removal of $\mathrm{CO}$ by the water-gas shift reaction, but it should not facilitate $\mathrm{C}-\mathrm{O}$ bond cleavage and hydrogenation of $\mathrm{CO}$ or $\mathrm{CO}_{2}$, which produce light alkanes. The best catalysts yet found are metals (e.g., platinum or nickel) dispersed on supports. Addition of nickel, cobalt, or iron to form alloy-like structures with platinum supported on $\mathrm{Al}_{2} \mathrm{O}_{3}$ improves the activity by $3-5$ times. Nickel-tin catalysts have been found to perform similarly to the platinum-containing bimetallic catalysts.

Alkanes produced in this manner would provide a renewable source of transportation fuel that could fit into the current infrastructure. However, the heaviest of the alkanes produced is hexane, which has a low value as a fuel additive because of its low octane number; its transformation into the more valuable branched isomers can be carried out with existing catalytic technology, with the attendant costs.

Progress toward the production of heavier alkanes has been achieved by combining the above-mentioned process with one in which $\mathrm{C}-\mathrm{C}$ bond formation occurs before the final dehydration reaction; the $\mathrm{C}-\mathrm{C}$ bond formation takes place by base-catalyzed aldol condensation. This reaction links carbohydrate-derived moieties through the formation of $\mathrm{C}-\mathrm{C}$ bonds with the elimination of water, yielding heavier alkanes ranging from $C_{7}$ to $C_{15}$.

Catalytic processing of biomass-derived feedstocks in the presence of liquid-phase reactants appears to be a promising route to the production of alkanes and $\mathrm{H}_{2}$, but much more research is needed to evaluate the technological prospects. Work with actual biomass-derived feedstocks instead of pure compounds is needed, as is an evaluation of the economics.

\section{Future Options for Conversion of Carbon Dioxide}

$\mathrm{CO}_{2}$ is a product both of carbon-containing fuel combustion and a number of the processes for making the fuels. It would be advantageous to dispose of the $\mathrm{CO}_{2}$ in environmentally safe ways or, perhaps even better, to convert it into fuels or chemicals. One possibility for disposing of $\mathrm{CO}_{2}$ that has already been demonstrated in a few locations involves sequestration of $\mathrm{CO}_{2}$ from power plants in permanent underground reservoirs (see the sidebar by Benson et al. this issue). This solution will not be feasible in all locations, because it requires the availability of suitable underground reservoirs. A second possibility is the catalytic reduction of $\mathrm{CO}_{2}$ to $\mathrm{CO}$ using $\mathrm{H}_{2}$ as a reactant. $\mathrm{H}_{2}$ can be obtained with today's technology from hydrocarbons such as natural gas, but in the future, it might be formed from water electrochemically or photochemically, with the needed energy perhaps provided by the sun or nuclear power plants (see the article by Crabtree et al. in this issue). Economical processes and catalysts for such conversions are lacking; the discovery of such catalysts and the creation of technology for $\mathrm{CO}_{2}$ conversion is a massive 
challenge. Nature's photosynthetic apparatus might provide the inspiration for efficient conversion of sunlight into useful energy or reactants for catalytic fuel production from $\mathrm{CO}_{2}$ and water (see the sidebar by Gust et al. in the article by Farrell et al. in this issue).

\section{Acknowledgments}

We thank Prof. Abhaya Datye of the University of New Mexico for providing Figures 1 and 2. This article grew out of the authors' efforts in preparation of a report of a workshop on the theme of catalysis for energy applications sponsored by the U.S. Department of Energy (DOE), Office of Basic Energy Sciences. We thank DOE for support and the many panelists who contributed ideas to the report.

\section{References}

1. G. Ertl, H. Knözinger, J. Weitkamp, F. Schüth, Eds., Handbook of Heterogeneous Catalysis (Wiley-VCH, Weinheim, Germany, ed. 2, 2008).

2. This section is based in part on B.C. Gates, Catalytic Chemistry (Wiley, New York, 1992).

3. D. Kalakkad, S.L. Anderson, A.D. Logan, J. Pena, E.J. Braunschweig, C.H.F. Peden, A.K. Datye, J. Phys. Chem. 97, 1437 (1993).
4. Q. Xu, K.C.C. Kharas, A.K. Datye, Stud. Surf. Sci. Catal. 139, 157 (2001). 5. This section is based in part on J.G. Speight, The Chemistry and Technology of Petroleum, 4th Edition (CRC Press, New York, 2006).

6. G.A. Olah, A. Goeppert, G.K. Surya Prakash, Beyond Oil and Gas: The Methanol Economy (Wiley-VCH, Weinheim, Germany, 2006).

7. R.D. Perlack, L.L. Wright, A.F. Turhollow, R.L. Graham, B.J. Stokes, D.C. Ehrbach, "Biomass as Feedstocks for a Bioenergy and Bioproducts Industry: The Technical Feasibility of a Billion-Ton Annual Supply" (U.S. Department of Energy and U.S. Department of Agriculture, Washington, DC, April 2005; http:// feedstockreview.ornl.gov/pdf/billion_ton_vision.pdf) (accessed January 2008).

8. This section is based on G.W. Huber, J.A. Dumesic, Catal. Today 111, 119 (2006).

9. This section and the next are based in part on G.W. Huber, S. Iborra, A. Corma, Chem. Rev. 106, 4044 (2006).

10. J.R. Salge, B.J. Dreyer, P.J. Dauenhauer, L.D. Schmidt, Science 314, 801 (2006).

11. P.J. Dauenhauer, B.J. Dreyer, N.J. Degenstein, L.D. Schmidt, Angew. Chem., Int. Ed. 46, 5864 (2007).

12. A. de Klerk, R.J.J. Nel, R. Schwarzer, Ind. Eng. Chem. Res. 46, 2377 (2007). 13. A. de Klerk, Energy Fuels 21, 625 (2007).

14. R.R. Soares, D.A. Simonetti, J.A. Dumesic, Angew. Chem., Int. Ed. 45 3982 (2006).

15. J.N. Chheda, J.A. Dumesic, Catal. Today 123, 59 (2007).

16. Y. Roman-Leshkov, C.J. Barrett, Z.Y. Liu, J.A. Dumesic, Nature 447, 982 (2007).

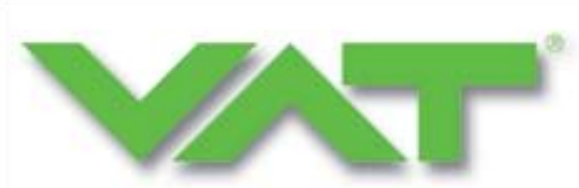

\section{XL-VAT Transfer Valve}

\section{Series 06.0 for FPD and Solar Cell Production Systems}
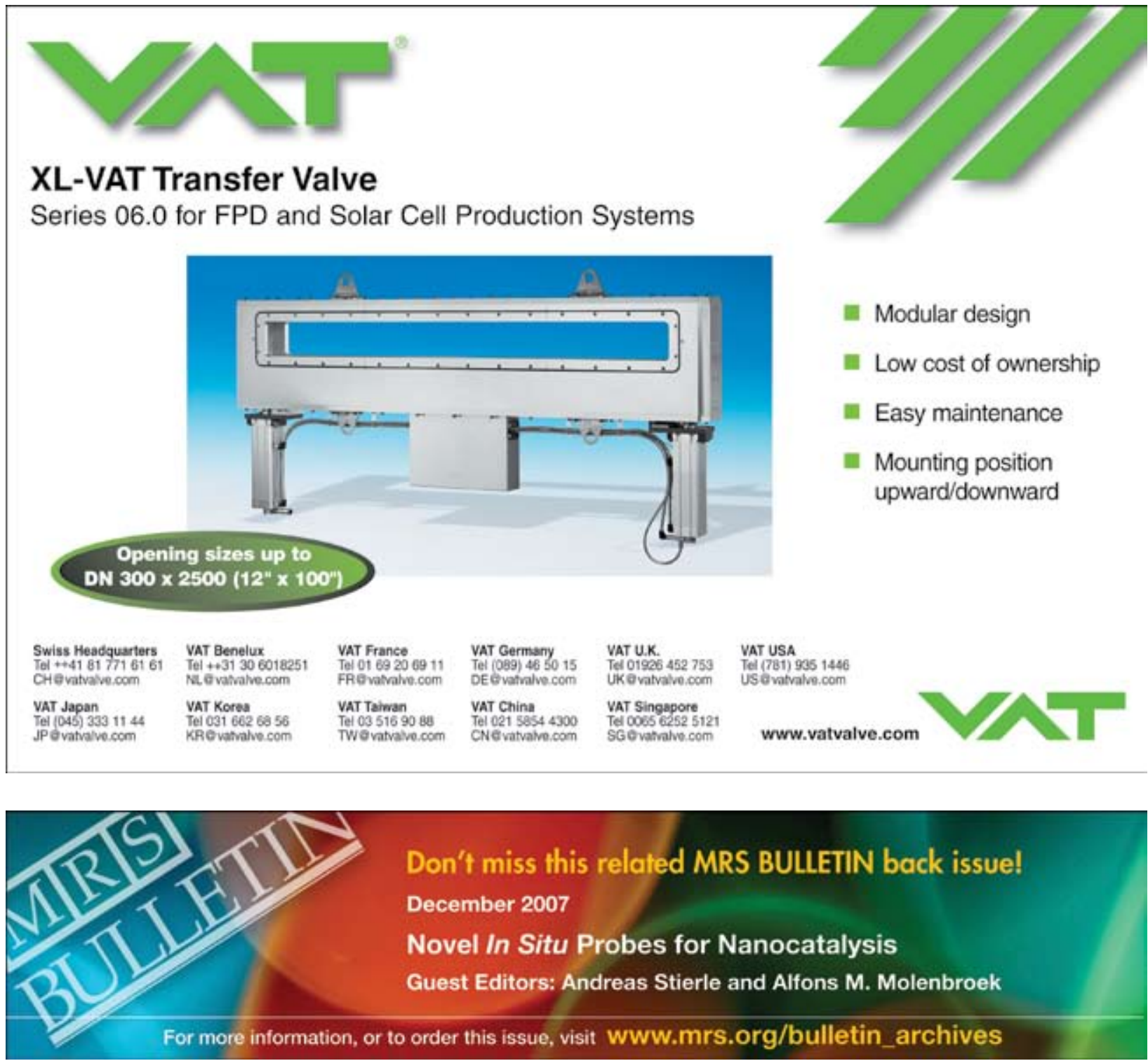


\section{Feeling the Heat?}

\section{AALDFILCH}

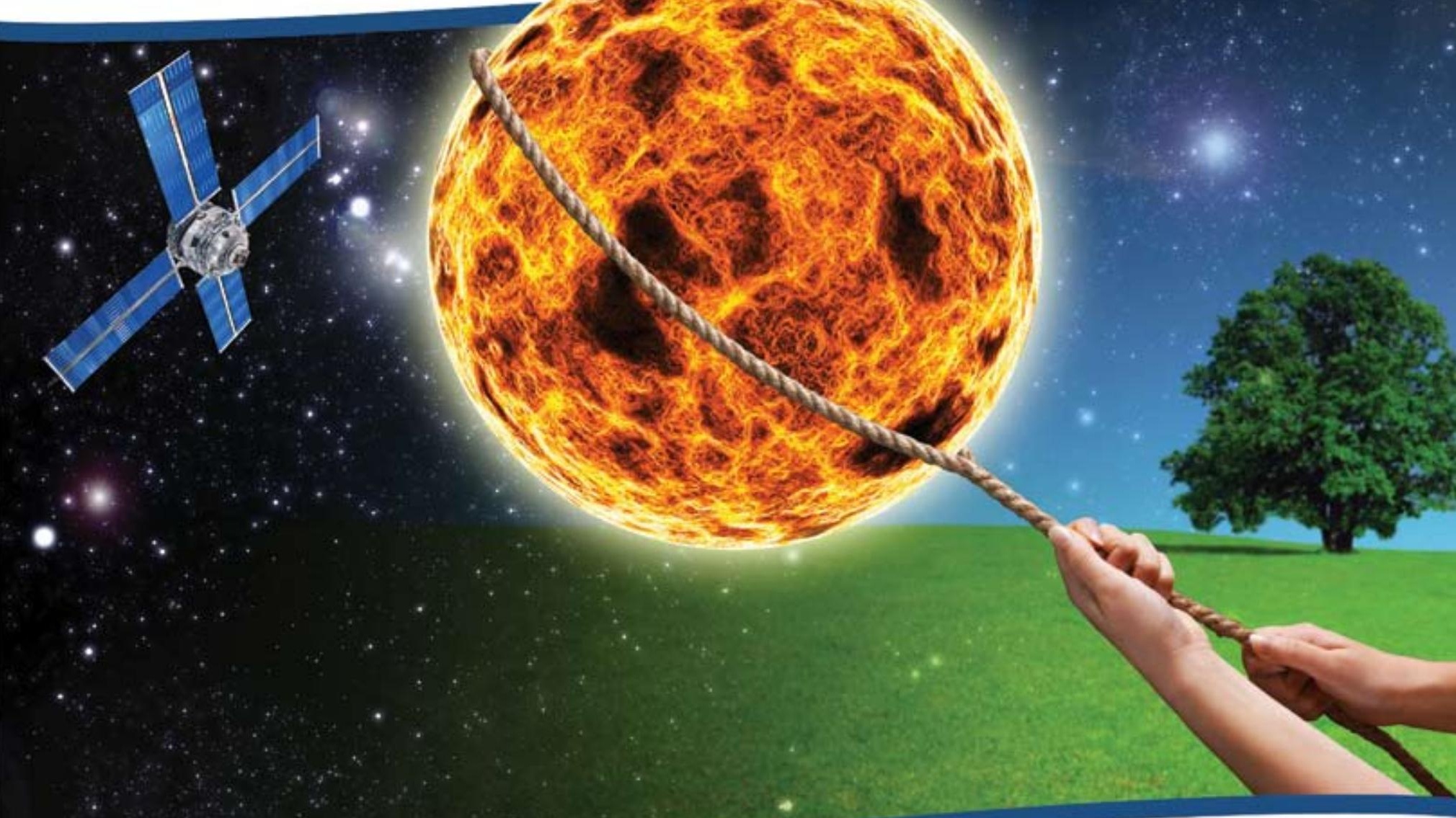

\section{Capture It!}

Aldrich Materials Science - helping to make Alternative Energy work for you.

\section{We focus on materials so you can focus on results.}

Materials for Organic Photovoltaics

- High Performance Polymers

- Organic Semiconductors

- Including P3HT and PCBM

- Hole and Electron Transporters

Visit sigma-aldrich.com/organicelectronics
Materials for Hydrogen Storage and Fuel Cells

- Metal Hydrides and Metal Alloys

- Metal Boron Hydrides and Ammonia Borane

- Linkers for MOFs

- PEMs, Electrode Materials, Nanomaterials

Visit sigma-aldrich.com/hydrogen

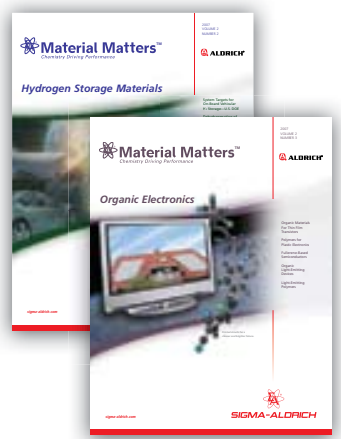

Material Matters ${ }^{\mathrm{T} m}$

Have you seen these issues on Alternative Energy?

If not, get your complimentary subscription today: sigma-aldrich.com/ $/ \mathrm{mm} 3$ 